\title{
間葉系幹細胞に由来する各種細胞の機能制御に関する研究
}

\author{
宝田剛 志
}

\section{Signaling Factors in a Variety of Cells Derived from Mesenchymal Stem Cells}

\author{
Takeshi Takarada \\ Laboratory of Molecular Pharmacology, Division of Pharmaceutical Sciences, \\ Kanazawa University Graduate School of Natural Science and Technology; \\ Kakuma-machi, Kanazawa, Ishikawa 920-1192, Japan.
}

(Received May 25, 2012)

\begin{abstract}
L-Glutamate (Glu) and $\gamma$-aminobutyric acid (GABA) has been thought to be an excitatory/inhibitory amino acid neurotransmitter in the mammalian central nervous system (CNS). Limited information is available in the literature with regard to an extracellular transmitter role of Glu and GABA in peripheral neuronal and non-neuronal tissues, whereas recent molecular biological analyses including ours give rise to a novel function for Glu and GABA as an autocrine and/or paracrine factor in a variety of cells derived from mesenchymal stem cells, in addition to other peripheral tissues including pancreas, adrenal, and pituitary glands. Emerging evidence suggests that Glu and GABA could play a dual role in mechanisms underlying maintenance of cellular homeostasis as a neurotransmitter in the CNS and as an extracellular signal mediator in peripheral autocrine and/or paracrine tissues. In this review, therefore, we summarized the possible signaling by Glu and GABA as an extracellular signal mediator in mechanisms underlying maintenance of cellular homeostasis in mesenchymal stem cells, osteoblasts and chondrocytes.
\end{abstract}

Key words—— mesenchymal stem cell; osteoblasts; chondrocytes; glutamate; $\boldsymbol{\gamma}$-aminobutyric acid (GABA)

\section{1. はじめに}

個体が構築されるまでの発生と成長段階だけでな く, 損傷や病態による組織欠損の修復には, 組織中 に存在する体性幹細胞が重要な役割を果たしてい る. その 1 つである間葉系幹細胞は, 自己複製能と ともに，骨芽細胞，軟骨細胞，脂肪細胞，筋細胞等 への多分化能を有する原始細胞である (Fig. 1). 1,2) 骨関節組織を構成する骨芽細胞及び軟骨細胞は，そ れぞれ骨密度の恒常性や関節の維持を担うととも に，骨粗鬆症を主とする骨代謝性疾患や，関節リウ マチ・変形性関節症などの関節疾患の病態発症に深 く関与する細胞種である。一方，脂肪細胞は脂肪組 織を構成し, 肥満やメタボリックシンドロームとの 関連性が近年注目されている.

多様な細胞の集団である組織においては, 細胞同

The author declares no conflict of interest.

金沢大学医薬保健研究域薬学系薬物学研究室 (T9201192 石川県金沢市角間町)

e-mail: takarada@p.kanazawa-u.ac.jp

本総説は, 平成 23 年度日本薬学会北陸支部学術奨励賞

の受賞を記念して記述したものである.
士が協調して機能するシステムを構築するために, 細胞間連絡を媒体する情報伝達物質は非常に重要な 役割を果たすと考えられる，それゆえ，細胞に対し

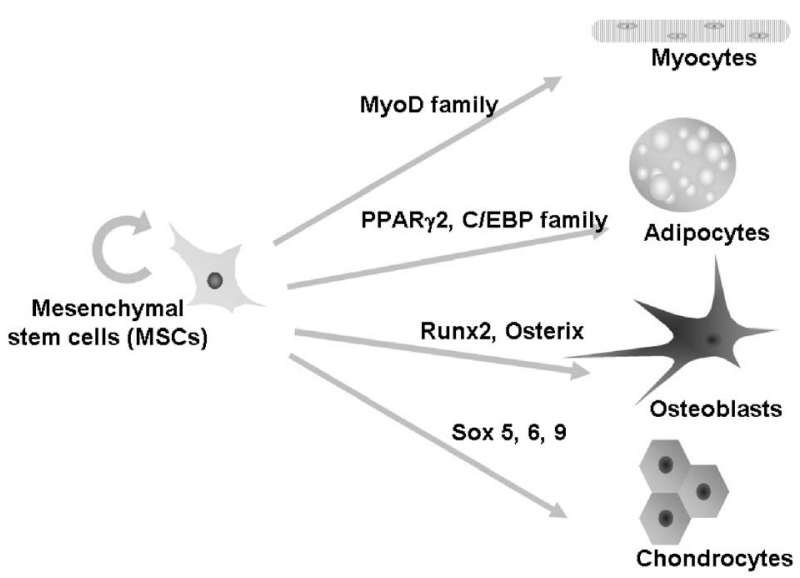

Fig. 1. Differentiation of Mesenchymal Stem Cells

Mesenchymal stem cells (MSCs) are multipotent cells capable of differentiating to myocytic, adipocytic, osteoblastic and chondrocytic lineages. The commitment to a particular lineage is regulated by specific transcription factors. For example, MSCs differentiate to myocytes under the control by MyoD family, to adipocytes under the control by C/EBP family and PPAR $\gamma 2$, to osteoblasts under the control by Runx2 and Osterix, and to chondrocytes under the control by Sox5, Sox6 and Sox9, respectively. 
て特異的あるいは重点的に作用する物質を新たに同 定することは，各細胞の分化・機能の制御機構の理 解に留まらず，疾患の予防又は病態に対する理解を 深める上で，重要な手がかりになると思われる。こ の細胞間ネットワーク形成には，ホルモン分泌に代 表される「エンドクライン」, サイトカイン等の分 泌による「オート・パラクライン」, 及び神経伝達 物質放出に伴う「ニューロクライン」が関与する. 間葉系幹細胞由来細胞群の機能制御機構に関して は，「エンドクライン」や「オート・パラクライン」 に関する知見は多く見受けられるが，「ニューロク ライン」シグナル分子に関する解析は，ほとんど行 われていないのが現状である。そこで本研究では, 興奮性あるいは抑制性神経情報伝達物質として知ら れている，グルタミン酸（Glu）及び $\gamma$-アミノ酪酸 （GABA）に注目して，間葉系幹細胞に由来する各 種細胞種の「ニューロクライン」シグナル分子によ る機能制御の可能性を追究した.

\section{2. 間葉系幹細胞の機能制御}

近年間葉系組織において, 脳内興奮性伝達物質と して知られる Glu のシグナル伝達機構に関する研 究が進み, 骨芽細胞及び筋芽細胞に Glu レセプ ターや同トランスポーターの機能的発現が確認され たことから，Gluがこれら細胞の分化・増殖・成熟 プロセスにおいて重要な役割を果たす可能性が示唆 されている。そこで，これら間葉系細胞の前駆細胞 においても Glu が情報伝達因子として働く可能性 があり, 生理学的作用の解明が必要と考えられたの で，本研究では間葉系幹細胞について，その増殖能 と分化能に対する Glu シグナル伝達機構関与の可 能性追究に着手した.

マウス胚細胞由来間葉系幹細胞株 C3H10T1/2 細 胞を用いて，未分化状態の細胞から total RNAを 抽出し, 各種 Glu レセプター, 及びトランスポー ターに特異的なプライマーを用いて，RT-PCR 法 によりそれぞれの mRNA 発現を解析した。 その結 果，C3H10T1/2 細胞には， N-methyl-D-aspartic acid (NMDA), DL- $\alpha$-amino-3-hydroxy-5-methylisoxasole-4-propianic acid (AMPA), kainic acid (KA) レセプター, 興奮性神経性アミノ酸トランスポー ター(EAATs)及び Cystine/Glu antiporter の mRNA 発現が認められた。

増殖期の $\mathrm{C} 3 \mathrm{H} 10 \mathrm{~T} 1 / 2$ 細胞を用いて, Glu 及び関
連試薬の持続的曝露による増殖に対する影響を MTT 還元能, LDH 活性, PI 染色性, BrdU 取り 込夕能, CyclinD1 プロモーター活性によって解析 した。その結果，Glu は C3H10T1/2 細胞の生存率 を濃度依存的に減少させたが，これは細胞死を伴わ ない増殖活性の抑制であることが明らかとなった。 また，各種受容体アゴニストは増殖能に著変を与え なかったが，Cystine 存在下では Glu による細胞生 存率の低下は有意に回復した。そこで，C3H10T1/ 2 細胞において Cystine の輸送活性を測定したとこ ろ，Glu 及び Cystine/Glu antiporter 阻害剤によっ て著明に減少し, Cystine/Glu antiporter の一過性 過㮃発現により，無刺激時に増殖能の有意な増加が 認められ，Glu 曝露により有意な細胞内 GSH 量の 減少が認められた。

C $3 \mathrm{H} 10 \mathrm{~T} 1 / 2$ 細胞及びマウス骨髄間質細胞におい て, Glu 曝露は骨芽細胞分化誘導による ALP 染色 性を有意に減少させ，一方で脂肪細胞分化条件化で は Oil Red O 染色性に著変を与えなかった。また, 骨芽細胞分化誘導条件下で観察された骨芽細胞分化 マーカーの type I collagen や osteocalcin の mRNA 発現は，Glu 曝露により有意に減少することが明ら かとなった。各種受容体アゴニストは ALP 染色性 に著変を与えず，Cystine 曝露は Glu による ALP 染色性，骨芽細胞マーカー mRNA 減少を有意に回 復させた．また，細胞内 GSH 量を測定したところ， Glu の曝露によって, GSH 量は有意に減少し, 酸 化ストレス応答遺伝子 Nrf2 の下流遺伝子 mRNA 発現の有意な上昇が確認された。また，Glu曝露は 核内での Runt related transcription factor 2 (Runx2) タンパク質量を有意に減少させた.

以上の結果より，C3H10T1/2 細胞において Glu レセプター及びトランスポーターが機能的に発現す る可能性が示された。 また，間葉系幹細胞の増殖能 に Glu は抑制的に働き，さらに，分化誘導条件下 において Glu は脂肪細胞分化には影響を与えず骨 芽細胞分化を抑制する可能性が示唆された。また,

Glu の作用メカニズムとして Cystine/Glu antiporter を介した細胞内 Cystine 量減少による GSH 量制 御が推察される。また，骨芽細胞の分化抑制効果は GSH 量減少とそれに続くNrf2 の活性化，さらに骨 芽細胞分化に必須の因子である Runx2 の核内移行 制御に起因する可能性が示唆される (Fig. 2). ${ }^{3,4)}$ 


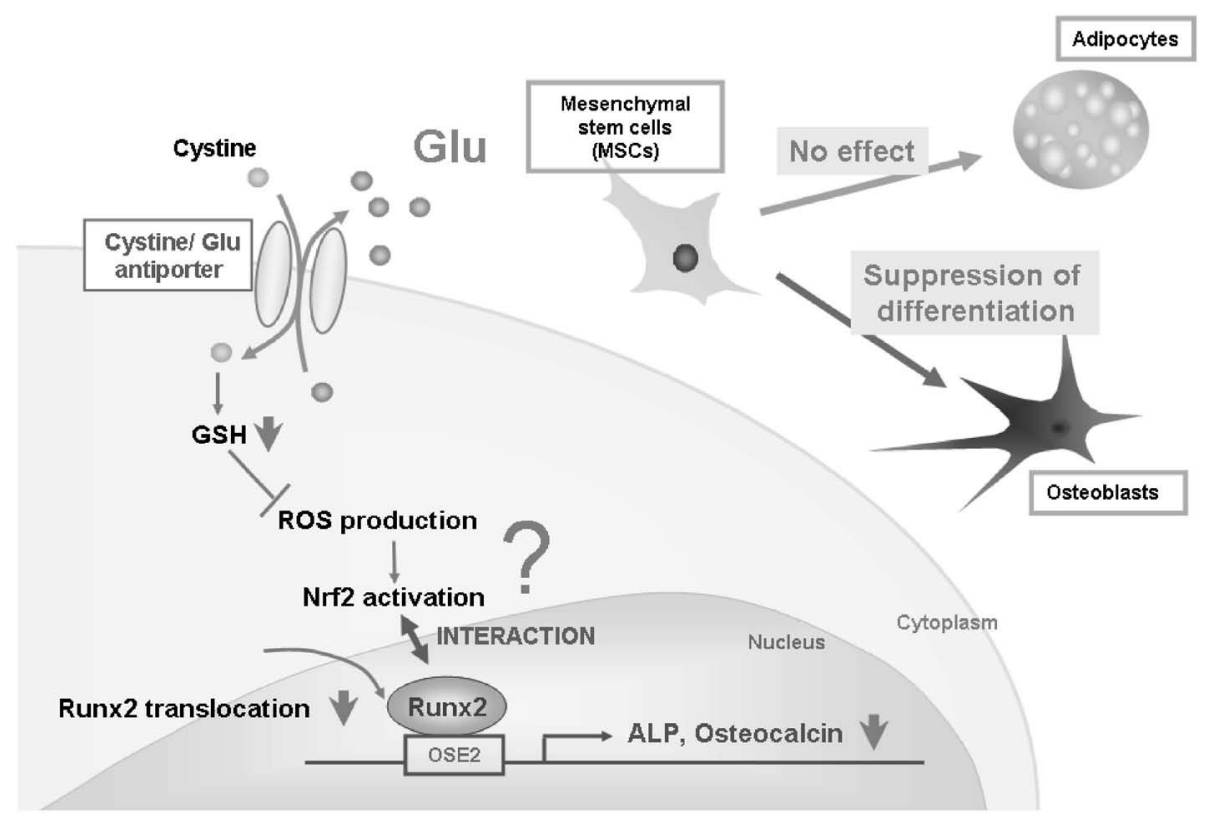

Fig. 2. Glu Signaling in MSC

Glutamate may inhibit osteoblastic differentiation, but not adipogenic differentiation, through a mechanism relevant to the nuclear translocation of Runx2 after the regulation of intracellular glutathione levels in association with the cystine/glutamate antiporter expressed by MSCs.

\section{3. 骨芽細胞の機能制御}

近年, 脳内抑制性伝達物質として知られる GABA のシグナル伝達機構の存在が末梢組織にも存在する ことが報告されている，本研究では，骨組織を構成 する骨芽細胞及び破骨細胞において GABA シグナ ル伝達機構の存在と, これらの細胞の増殖・分化・ 成熟プロセスにおいて GABA シグナル伝達機構の 関与の可能性について追求した。

骨形成を担う骨芽細胞には $\mathrm{GABA}_{\mathrm{B}}$ 受容体を構成 する $\mathrm{GABA}_{\mathrm{B}} \mathrm{R} 1$ サブユニットと $\mathrm{GABA}_{\mathrm{B}} \mathrm{R} 2$ サブユ ニットのいずれも発現が確認されたのに対して，骨 吸収を担う破骨細胞では $\mathrm{GABA}_{\mathrm{B}} \mathrm{R} 1$ 及び $\mathrm{GABA}_{\mathrm{B}}$ $\mathrm{R} 2$ サブユニットいずれも発現は認められなかっ た. 生後 1 日目のマウスの骨格標本を解析した結果, $\mathrm{GABA}_{\mathrm{B}} \mathrm{R} 1$ 欠損マウスでは内軟骨性骨化部位である 舌骨, 中足骨で野生型マウスに比べ石灰化の遅延が 認められたが，膜性骨化部位で知られる鎖骨では変 化がみられなかった。 また生後 8 週齢マウスの大腿 骨，及び脛骨の骨密度や長さを測定したところ， $\mathrm{GABA}_{\mathrm{B}} \mathrm{R} 1$ 欠損マウスでは野生型マウスに比べ骨密 度の有意な低下と長さの減少が観察された.

$\mathrm{GABA}_{\mathrm{B}}$ 受容体欠損骨芽細胞では，骨芽細胞成熟 の指標である ALP 活性, $\mathrm{Ca}^{2+}$ 蓄積能ともに野生 型骨芽細胞に比べ, 著明に増加した。一方, 破骨細 胞分化能を検討した結果, $\mathrm{GABA}_{\mathrm{B}}$ 受容体欠損破骨
細胞と野生型破骨細胞の形成能や骨吸収能に変化は みられなかった。 $\mathrm{GABA}_{\mathrm{B}}$ 受容体欠損骨芽細胞と破 骨細胞を共培養することにより, 野生型骨芽細胞と 共培養するのに比べて, 破骨細胞形成は有意に増加 した．さらに骨芽細胞由来因子で，破骨細胞分化促 進作用の知られている RANKL の発現量を定量化 した結果, $\mathrm{GABA}_{\mathrm{B}}$ 受容体欠損骨芽細胞では野生型 骨芽細胞に比べ RANKL 発現量は有意に増加して いることが明らかとなった。

以上の結果より, 骨芽細胞において $\mathrm{GABA}_{\mathrm{B}}$ 受容 体が機能的に発現し，骨芽細胞成熟を抑制的に調節 するが，RANKL の発現も調節することで破骨細胞 形成についても影響を与える可能性が示唆された (Fig. 3).5)

\section{4. 軟骨細胞の機能制御}

GluR の一種である NMDA 受容体には, Strychnine 非感受性 Glycine（Gly）結合部位が存在するが, この Gly 部位は Serine racemase（SR）により生合 成された D-Serine（D-Ser）により機能調節を受け ることが中枢神経系においては知られている. ${ }^{6}$ 本 研究では, 軟骨細胞におけるこれら因子の発現解析 を行うとともに, NMDA 受容体の活性修飾因子で ある D-Ser の骨関節組織における機能的意義を追 究した.

まず，軟骨組織における各種 NMDA 受容体サブ 


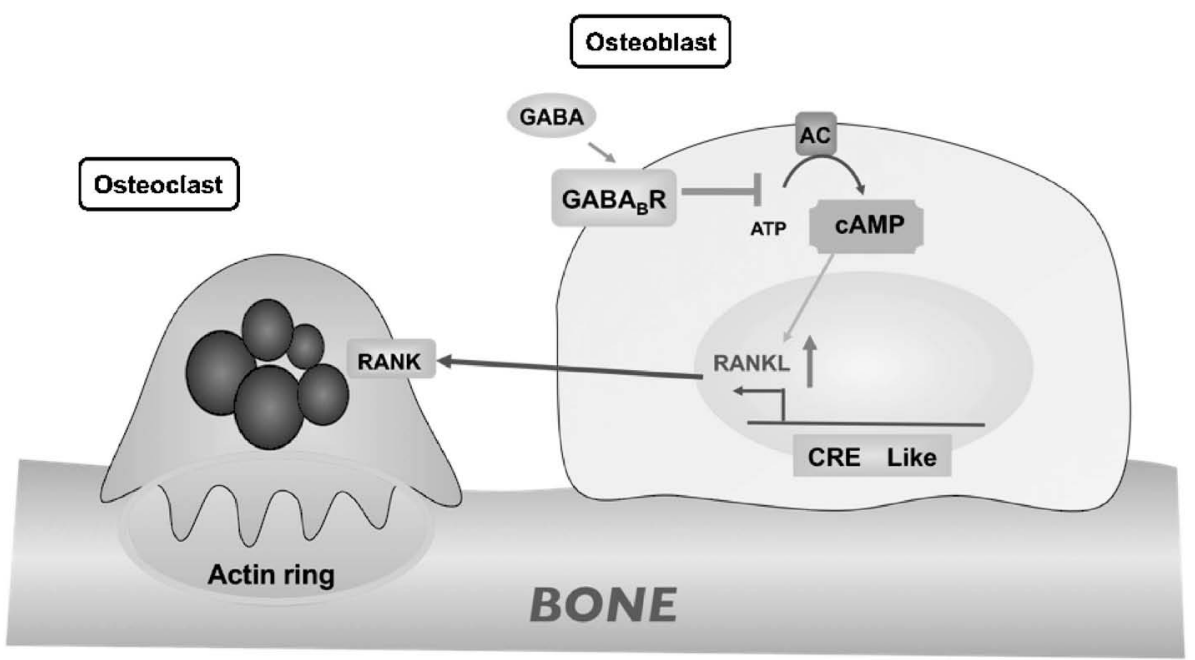

Fig. 3. GABA Signaling in Osteoblasts

GABA may play a pivotal role in mechanisms underlying the negative regulation of osteoblastogenesis and osteoclastogenesis through the down-regulation of RANKL expression essential for each cellular differentiation and maturation after activation of $\mathrm{GABA}_{\mathrm{B}} \mathrm{R}$ predominantly expressed at osteoblastic cellular surfaces.

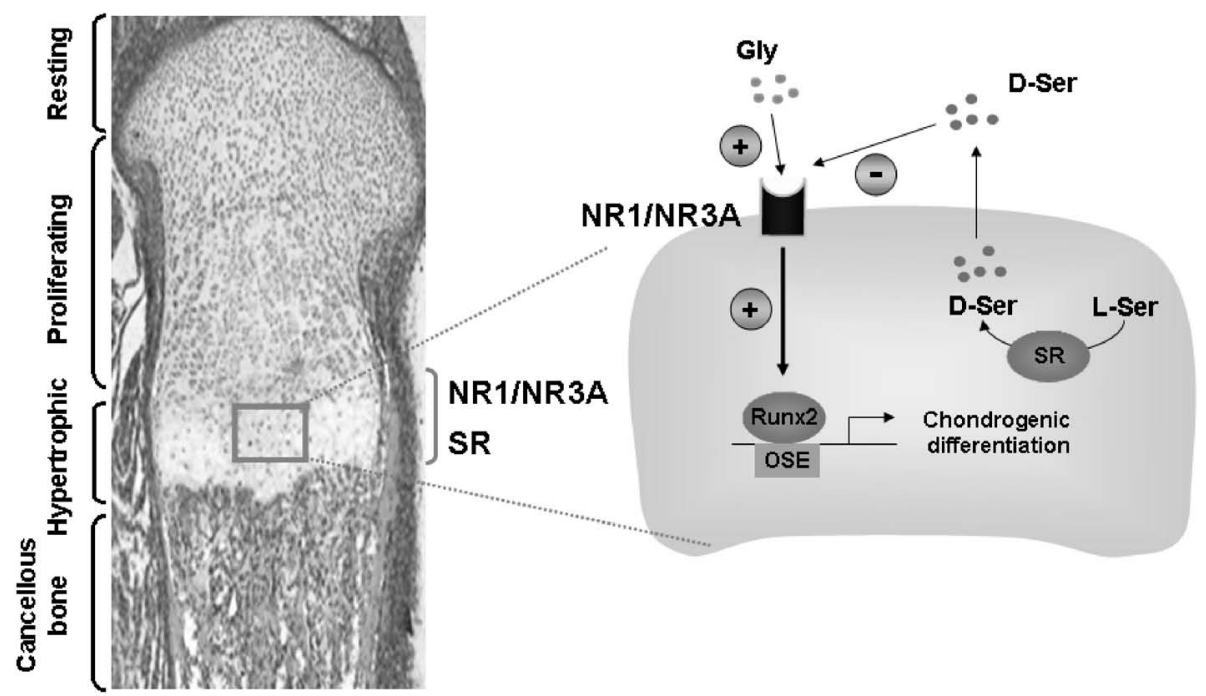

Fig. 4. Glu Signaling in Chondrocytes

D-Ser would be synthesized from intracellular L-Ser by the catalytic action of SR expressed by chondrocytes at different developmental stages for subsequent release into extracellular space. Extracellular D-Ser could then inhibit as an antagonist for the Gly-operated NMDAR composed of NR1 and NR3A subunits expressed by hypertrophic chondrocytes, followed by interference with Runx2 transcriptional activity toward delayed chondrocyte differentiation.

ユニットの発現を検討したところ，初代培養軟骨細 胞において NR1，NR2D 及びNR3A の mRNA 発現 が認められたが，これらの発現は肥大化軟骨細胞層 に限局することが明らかとなつた。また，培養軟骨 細胞では NMDA 受容体アゴニストである Gly は, 後期分化過程の指標である細胞石灰化を有意に促進 したが，この促進効果は Gly 部位の antagonist で ある 5,7-dichlorokynurenic acid だけでなく, D-Ser によっても有意に拮抗された。しかしながら，抑制 性 Gly 受容体 antagonist である Strychnine や Gly transporter 阻害剤である Sarcosine は，この Gly の 促進作用に対して著明な変化を与えなかった。この 成熟促進作用の細胞内メカニズムを検討する目的 で, 後期分化過程を制御する転写因子 Runx2 に注 目した。その結果, Glyは Runx2の mRNA 発現に 対しては著変を与えないのに対して, Runx2 の転 写活性化能を有意に促進したが，この効果は D-Ser により有意に拮抗された。前述の薬理学的特性と転 写活性化能解析結果から，Glyによる軟骨細胞成熟 促進作用は, NR1/NR2D よりはむしろ NR1/NR3A 
から構成される NMDA 受容体を介する可能性が示 唆される.

次に D-Ser 合成酵素である SR の軟骨組織におけ る機能的発現の可能性を検討した。軟骨組織切片上 では，すべての軟骨細胞層に SR の mRNA 発現が 認められただけでなく，初代培養軟骨細胞において もSR の発現が認められた。さらに，培養軟骨細胞 においては D-Ser 放出活性が検出された。 以上の 結果より，Gly は NMDA 受容体を介して後期軟骨 細胞分化過程に対して促進的に作用するのに対し て，軟骨組織に発現する SR より合成された D-Ser は Glyによる分化促進作用に対して拮抗的に作用 する可能性が考えられる (Fig. 4).7-9)

\section{5. おわりに}

以上より，間葉系幹細胞及び由来細胞種におい て，ニューロクラインシグナル分子による機能制御 機構が存在する事実が明らかとなった。本研究成績 は，これら細胞の増殖・分化メカニズムの解明だけ でなく, 細胞機能破綻に起因する疾患への治療学的 アプローチの重要な足掛かりになると考えられる. 今後, 間葉系幹細胞由来の各種細胞種における二 ユーロクライン分子の生理学的及び病態生理学的重 要性を認識することにより, 各種疾患治療に新たな 展望をもたらすことが期待される.

謝辞本研究を遂行する上において終始ご懇切 なるご指導とご鞭撻を賜りました，金沢大学医薬保
健研究域薬学系・米田幸雄教授及び檜井栄一准教授 に厚く御礼申し上げます。また，多大なるご協力と ご援助を頂きました金沢大学医薬保健研究域薬学 系・薬物学研究室の皆様に深く感謝いたします。

\section{REFERENCES}

1) Colter D. C., Sekiya I., Prockop D. J., Proc. Natl. Acad. Sci. USA, 98, 7841-7845 (2001).

2) Umezawa A., Maruyama T., Segawa K., Shadduck R. K., Waheed A., Hata J., J. Cell. Physiol., 151, 197-205 (1992).

3) Iemata M., Takarada T., Hinoi E., Taniura H., Yoneda Y., J. Cell. Physiol., 213, 721-729 (2007).

4) Takarada-Iemata M., Takarada T., Nakamura Y., Nakatani E., Hori O., Yoneda Y., $J$. Cell. Physiol., 226, 652-665 (2011).

5) Takahata Y., Takarada T., Hinoi E., Nakamura Y., Fujita H., Yoneda Y., J. Biol. Chem., 286, 32906-32917 (2011).

6) Oliet S. H., Mothet J. P., Glia, 54, 726-737 (2006).

7) Takahata Y., Takarada T., Osawa M., Hinoi E., Nakamura Y., Yoneda Y., Cell Tissue Res., 333, 91-103 (2008).

8) Takarada T., Hinoi E., Takahata Y., Yoneda Y., J. Cell. Physiol., 215, 320-328 (2008).

9) Takarada T., Takahata Y., Iemata M., Hinoi E., Uno K., Hirai T., Yamamoto T., Yoneda Y., J. Cell. Physiol., 220, 756-764 (2009). 